O. А. Гура,

к.е.н., доцент, Одесъкий фінансово-економічний коледж

Київського начіонального торговельно-економічного університету, м. Одеса, Украӥна

ORCID ID: 0000-0002-8526-8844

B. A. Бобівсъкий,

студент, Одесъкий фінансово-економічний коледж

Київсъкого начіонального торговельно-економічного університет, м. Одеса, Украӥна

ORCID ID: 0000-0002-0663-5432

\title{
СТРАТЕГІЯ РОЗВИТКУ ПІАПРИЕМСТВ В УКРАЇНІ
}

O. Gura,

PhD in Economics, Odessa Financial and Economic College

of Kyiv National University of Trade and Economics, Odessa, Ukraine

V. Bobovskyy,

Student, Odessa Financial and Economic College

of Kyiv National University of Trade and Economics, Odessa, Ukraine

\section{ENTERPRISE DEVELOPMENT STRATEGY IN UKRAINE}

РозгАянуто основні характеристики, які відображають сутність стратегї розвитку підприємства. Наведено, що сучасні економічні умови, у яких працюють підприємства, можна охарактеризувати як динамічні та невизначені. ОАним з основних чинників, які можуть забезпечити підприемству стійкість на ринку та сприяти посиленню його позицій, є належним чином обгрунтована стратегія розвитку.

ОАним 3 найбільш актуальних завдань СУчасного розвитку економіки України с Створення умов ефективного і,динамічного функціонування в ринкових відносинах. Водночас важАивою є реорганізація надмірної концентрації і монополізації виробництва, удосконалення організаційних і структурних відноСин, перегляд застарілих командних економічних зв'язків і методів керування.

Обгрунтовано необхідність розвитку підприємницької активності, діяльність підприємств і організацій, Спрямованих на споживача, і кінцевий результат - прибуток. ПіА впливом процесів реформування економіки в Україні поступово складається нова фінансова Система, яка включає в Себе різноманітні фінансові відносини, пов'язані з утворенням і використанням грошових ресурсів, а також сукупність фінансових установ країни.

Враховано, що за нинішніх умов фінанси розширили межі свого впливу, усе більш актуальним Стає завдання розробки методів і прийомів ефективного використання обмежених фінансових ресурсів, інвеСтування коштів в активи чи проекти, що забезпечують,доходи за допустимого ризику.

У Статті, досліджено основні характеристики стратегї̈ розвитку, на підставі яких запропоновано піА Стратегією розвитку підприемства розуміти довгостроковий гнучкий пАан дій інноваційного спрямування 3 відповідним рівнем ризику, який базується на детальному аналізі внутрішнього і зовнішнього середовища підприємства, залежить від Аюдських чинників та потребує інвестицій дАя, осягнення ефективних результатів, підвищення конкурентоспроможності продукції і підприемства.

The main characteristics that reflect the essence of the enterprise development strategy are considered. It is stated that the current economic conditions in which the enterprises operate can be described as dynamic and uncertain. One of the main factors that can provide an enterprise with stability in the market and strengthen its position is a well-founded development strategy.

Of particular importance is the risk analysis of the enterprise development strategy, as modern enterprises operate in a dynamic market with a high degree of uncertainty in the parameters of the external environment and are exposed to a large number of risks, so the risk analysis of enterprise development strategies becomes especially relevant.

One of the most urgent tasks of the modern development of the Ukrainian economy is to create conditions for an effective and dynamic transition to market relations. At the same time, it is very important to reorganize the excessive concentration and monopolization of production, improve organizational and structural relations, revise outdated command economic relationships and management methods. 


\section{ЕКОНОМІЧНА НАУКА}

In these conditions, the need for the development of entrepreneurial activity, the activity of enterprises and organizations aimed at the consumer, and the end result - profit, becomes particularly acute.

Under the influence of economic reform processes in Ukraine, a new financial system is gradually emerging, which includes various financial relationships related to the creation and use of monetary resources, as well as the totality of the country's financial institutions.

Given that, in the current context, finance has expanded its scope of influence, the task of developing methods and techniques for the efficient use of scarce financial resources, investing in assets or projects that generate income at acceptable risk is becoming increasingly relevant.

The article explores the main features of the development strategy, which underlies the enterprise development strategy to understand the long-term flexible plan of innovative orientation with the appropriate level of risk, based on a detailed analysis of the internal and external environment of the enterprise, depends on human factors and requires investment to achieve effective results, improving the competitiveness of products and businesses.

Ключові слова: стратегія підприємства, види стратегій, інновачіи, інновачійна діяльність, стратегічні чілі, стратегічне бачення, економічна сталість.

Key words: enterprise strategy, types of strategies, innovations, innovation activity, strategic goals, strategic vision, economic sustainability.

\section{ПОСТАНОВКА ПРОБЛЕМИ}

Жорстка конкурентна боротьба на світових ринках потребує від України пошуку шляхів підвищення конкурентоспроможності національної економіки, формування у країні потужного інноваційного та науково-технічного потенціалу. Однак високий ступінь конкурентоспроможності промислових підприємств та країни в цілому характеризується наявністю механізмів формування й забезпечення умов, засобів, які зумовлюють їх розвиток та підвищення добробуту населення.

\section{АНАЛІЗ ОСТАННІХ ДОСЛІДЖЕНЬ І ПУБЛІКАЦІЙ}

Проблеми розвитку підприємства в Україні досліджено на основі аналізу робіт вчених: І.Ю. Епіфанова, М.Ю. Азюбко, О.І. Гудзь, О.О. Плахотнік, I.М. Чернявська та ін. В умовах розвитку економіки від менеджменту підприємства потрібна підвищена винахідливість і гнучкість у використанні різних стратегій, кожна 3 яких повинна мати на меті вихід на більш високий або сталий етап розвітку бізнесу. У цій діяльності важливо визначитися в головному - який тип стратегії обрати в конкретній ситуації з розрахунком на перспективу. Теоретичні й практичні аспекти цієї проблеми відображено в роботах учених і фахівців: I.Т. Балабанова, I.О. Бланка, Є. Брігхема, Аж.К. Ван Хорна, В.М. Геєца, М.Г. Гузя, А. Аайле, П.Арукера, П.В. Єгорова, А.М. та ін.

\section{META CTATTI}

Метою наукової статті $є$ дослідження теоретичних і практичних аспектів стратегї̈ розвитку підприємства, ïi вибір і обгрунтування, а також розробка на цій підставі шляхів удосконалення на основі стратегічного аналізу зовнішнього та внутрішнього середовища.

\section{ВИКЛАД ОСНОВНОГО МАТЕРІАЛУ}

3 метою досягнення безперервного зростання обсягів діяльності підприємство повинно формувати власну стратегію розвитку.

Стратегія підприємства - це процес формування генерального перспективного напряму розвитку підприємства на основі визначення якісно нових цілей, узгодження внутрішніх можливостей підприємства 3 умовами зовнішнього середовища та розробка комплексу заходів, які забезпечують їх досягнення [7].

Отже, стратегію розвитку підприємства можна охарактеризувати як довгостроковий гнучкий план дій інноваційного спрямування 3 відповідним рівнем ризику, який базується на детальному аналізі внутрішнього і зовнішнього середовища підприємства, залежить від людських чинників та потребує інвестицій для досягнення ефективних результатів, підвищення конкурентоспроможності продукції і підприємства. Основні характеристики стратегії розвитку представлено на рисунку 1.

На практиці підприємства застосовують так звані базисні, або еталонні, стратегії розвитку бізнесу (рис. 2):

- стратегії концентрованого зростання, що пов'язані зі зміною продукту і (чи) ринку;

- стратегії інтегрованого зростання;

- стратегії диверсифікованого зростання;

- стратегії скорочення.

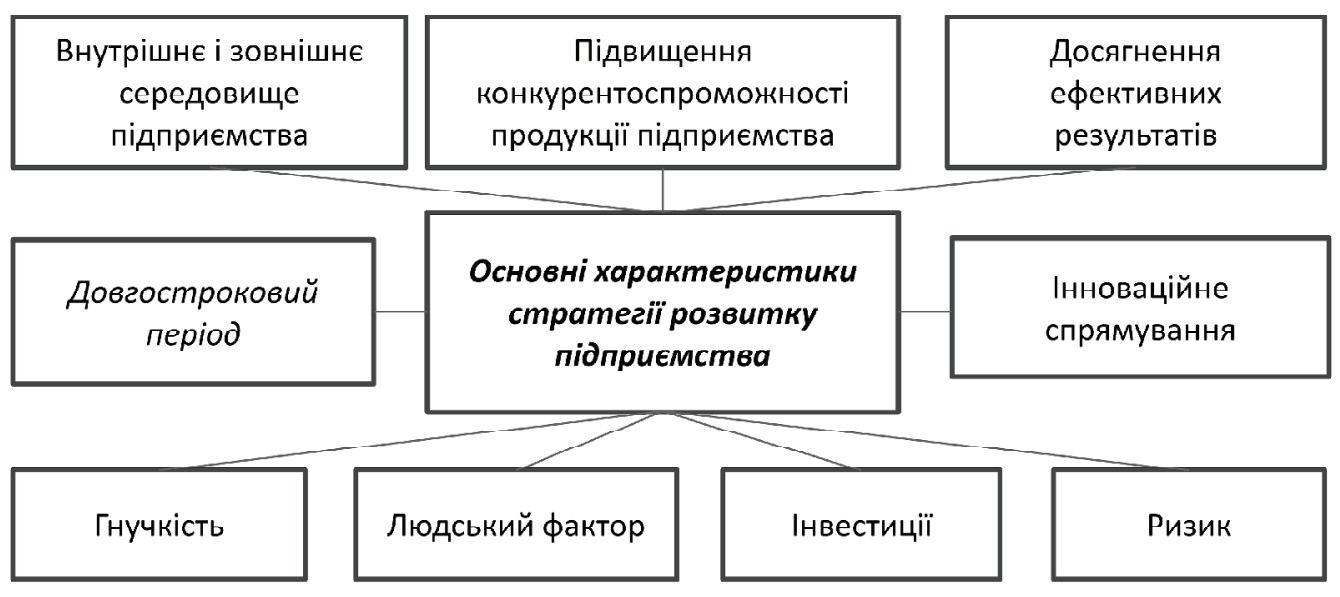

Рис. 1. Основні характеристики, які відображають сутність стратегї̈ розвитку підприємства 


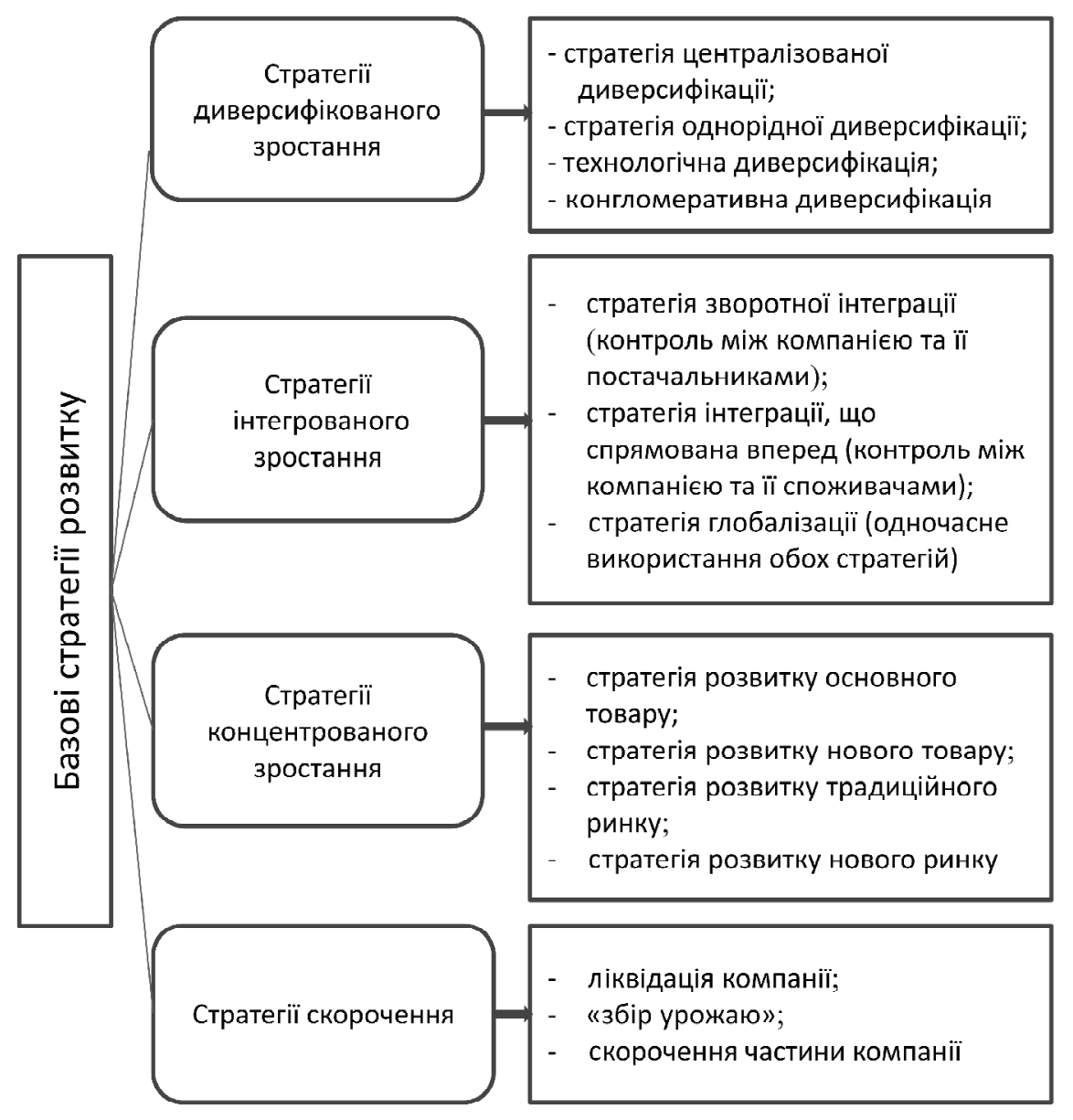

Ажерело: [3].

Використовуючи стратегію концентрованого зростання підприємство намагається поліпшити або виробляти новий продукт, не змінюючи галузі. Підприємство також веде пошук можливостей для того, щоб поліпшити своє становище на наявному ринку або ж для переходу на новий ринок.

Стратегії інтегрованого зростання пов'язані з розширенням підприємства через додавання нових структур. Підприємству доцільно використовувати цю стратегію, коли воно перебуває в сильному бізнесі, але не може здійснювати стратегії концентрованого зростання. Водночас інтегроване зростання не суперечить довгостроковим цілям підприємства. Підприємство може здійснювати інтегроване зростання шляхом придбання власності або розширення зсередини. Водночас в обох випадках змінюється положення.

Стратегія диверсифікованого зростання реалізується тоді, коли підприємство далі не може розвиватися на цьому ринку із цим продуктом у рамках цієї галузі. Як правило, основні фактори, що впливають на вибір стратегії диверсифікованого зростання, такі:

- ринки знаходяться в стані насичення або ж скорочення попиту на продукт, який перебуває в стадії занепаду;

- поточний бізнес потребує значних грошових надходжень, що можуть бути вкладені в більш прибутковий;

- новий бізнес може викликати ефект синергії за рахунок ефективного використання устаткування, комплектуючих виробів, сировини тощо;

- антимонопольне законодавство не дає можливості розширювати бізнес у рамках галузі;

- скорочення податкових витрат;

- полегшення виходу на світові ринки;

- залучення нових кваліфікованих службовців або ефективне використання потенціалу наявних менеджерів.

Стратегію скорочення використовують Аля цілеспрямованого згортання виробництва.

На практиці підприємство може одночасно реалізовувати кілька стратегій.

Основними елементами стратегічного управління є підприємство та зовнішнє середовище. Підприємство, яке $\epsilon$ складовою частиною зовнішнього середовища, для забезпечення ефективної діяльності повинне вміти адаптуватися до наявних та можливих змін зовнішнього середовища. Зовнішньому середовищу, яке є динамічною системою, властиві постійні зміни. Підприємство як складова частина даної схеми повинне завжди оперативно реагувати на такі зміни. Саме тому успіху можуть досягнути не ті підприємства, які здатні сформувати вдалу стратегію, а ті, які здатні вчасно адаптувати іiі згідно із змінами та враховувати ризики [3].

Стратегічне управління можна розглядати як динамічну сукупність п'яти, взаємопов'язаних управлінських процесів. Ці процеси логічно складають один цілісний механізм, всередині якого існує стійкий зворотний зв'язок і, відповідно, зворотний вплив кожного процесу на інші і на всю їх сукупність. Саме у цьому полягає важлива особливість структури стратегічного управління.

Аналіз середовища вважається першим процесом стратегічного управління, оскільки він забезпечує основу як для визначення місії і цілей фірми, так і для розробки стратегії. Одним з ключових завдань будь-якого управління є підтримання балансу у взаємодії підприємства 3 навколишнім середовищем. Кожне підприємство задіяне у трьох комутативних процесах: (вхід); 
- перетворення ресурсів у продукт (перетворення); - передача продукту у зовнішнє середовище (вихід).

Управління покликане забезпечувати баланс входу і виходу. Як тільки цей баланс порушується, підприємство потрапляє в кризу [5].

Розробка стратегії діяльності підприємства здійснюється поетапно:

1 етап - усвідомлення місії підприємства. Під місією підприємства прийнято розуміти генеральну глобальну ціль (причину, мотив) створення та функціонування підприємства (з точки зору його власників).

2 етап - вивчення стану зовнішнього середовища та ступеня його впливу на діяльність підприємства.

3 етап - оцінка сильних та слабких сторін діяльності підприємства (аналіз ефективності господарськоӥ діяльності, оцінка конкурентоспроможності підприємства, визначення конкурентного статусу.

4 етап - формування системи стратегічних цілей розвитку підприємства.

Процес формування цілей складається з двох взаємопов'язаних етапів роботи:

- якісного визначення цілей (наприклад, завоювання ринку, досягнення достатнього збільшення прибутку для фінансування діяльності підприємства або входження в нові сфери та ін.);

- уточнення, узгодження конкретизації та кількісного визначення поставлених цілей у вигляді системи найважливіших показників господарської діяльності, яких прагне досягти підприємство у визначений період часу.

5 етап - розробка стратегічних альтернатив розвитку підприємства та їх оцінка (вибір).

Оцінка розроблених стратегічних альтернатив та вибір найбільш доцільної для реалізації проводиться за наступними основними параметрами:

- узгодженість стратегії із зовнішнім середовищем;

- внутрішня збалансованість стратегії;

- реалізованість стратегії з урахуванням наявного ресурсного потенціалу підприємства;

- прийнятність рівня ризиків, пов'язаних із здійсненням стратегії;

- результативність стратегії.

6 етап - здійснення заходів, що спрямовані на реалізацію розробленої стратегії розвитку підприємства:

- розробка системи забезпечуючих (функціональних) стратегій;

— формування політики підприємства за окремими найважливішими напрямками діяльності;

- розробка системи тактичних планів ведення господарсько-фінансової діяльності.

7 етап - моніторинг ходу реалізації стратегії та оцінка необхідності її коригування [8].

Розрізняють певні організаційні рівні побудови стратегій у диверсифікованих та вузько профільних компаніях.

Так, у диверсифікованих компаніях розробляють стратегї̈ на чотирьох рівнях:

— корпоративному;

- діловому;

— функціональному;

- операційному.

Корпоративна (загальна) стратегія визначає загальний напрямок діяльності підприємства а саме:

стратегія зростання - стратегічна альтернатива, що характеризується цілями, які набагато перевищують рівень минулих досягнень;

стратегія обмеженого зростання (стабілізації) стратегічна альтернатива, що характеризується цілями, які визначені на рівні минулих досягнень, скоригованих з урахуванням інфляції;

стратегія скорочення - стратегічна альтернатива, яка характеризується встановленням цілей, які нижчі від рівня, досягнутого в минулому або виключенням окремих напрямків діяльності.
У вузько профільному підприємстві використовують три рівні побудови стратегій. Аілова стратегія в цьому разі є водночас корпоративною.

Шляхи досягнення підприємством бажаного результату (зростання, обмеженого зростання, скорочення) визначає конкурентна стратегія.

Конкурентна (ділова) стратегія - це план управління окремою сферою діяльності компанії, що грунтується на діях і підходах, спрямованих на забезпечення успішної діяльності в одній специфічній сфері бізнесу. Конкурентна стратегія визначає, як завоювати сильні довгострокові конкурентні позиції. Цю стратегію ще називають діловою, стратегією бізнесу або стратегією конкурентоспроможності.

Функціональні стратегії розробляються для кожного функціонального напрямку певної сфери діяльності. У кожній сфері діяльності передбачається розробка стратегії виробництва, науково-дослідних і дослідноконструкторських робіт, маркетингу, фінансів та ін.

Операційна стратегія - більш вузька стратегія для основних структурних одиниць: заводів, торгових регіональних представників і відділів. Операційні стратегії розробляються всередині функціональних напрямів [2].

Інвестиційна стратегія являє собою систему довгострокових цілей інвестиційної діяльності підприємства, обумовлених загальними завданнями його розвитку й інвестиційною ідеологією, а також вибір найбільш ефективних шляхів їхнього досягнення.

Інвестиційну стратегію представляють як генеральний план дій у сфері інвестиційної діяльності підприємства, що визначає пріоритети їі напрямків і форм, характер формування інвестиційних ресурсів і послідовність етапів реалізації довгострокових інвестиційних цілей, що забезпечують передбачений загальний розвиток підприємства [4].

Формування інвестиційної стратегії підприємства базується на прогнозуванні:

— окремих умов здійснення інвестиційної діяльності (інвестиційного клімату),

- кон'юнктури інвестиційного ринку як загалом, так і щодо окремих його сегментів.

Початковим етапом розробки інвестиційної стратегії підприємства є визначення загального періоду їі формування, який залежить від ряду умов. Головною умовою $є$ передбачуваність розвитку економіки загалом й інвестиційному ринку зокрема. В умовах нестабільного розвитку економіки країни цей період не може бути занадто тривалим і в середньому становить $3-5$ років.

Важливими умовами визначення періоду формування інвестиційної стратегії є:

- тривалість періоду формування загальної економічної стратегії підприємства, тобто інвестиційна стратегія не може виходити за межи цього періоду;

- галузева належність підприємства, а також однією з умов визначення періоду формування інвестиційної стратегії $є$ розмір підприємства. Інвестиційна діяльність великих підприємств звичайно прогнозується на більш тривалий період;

- взаємозв'язок з системою цілей загальної стратегії економічного розвитку. Спрямованість цілей може бути різноманітною - забезпечення приросту капіталу; зросту рівня прибутковості інвестицій і суми доходу від інвестиційної діяльності; зміна пропорцій реального і фінансового інвестування; зміни технологічної і відтворювальної структури капітальних вкладень; зміни галузевої і регіональної спрямованості інвестиційних програм і та ін.

Аля оцінки ефективності інвестиційної стратегії використовують наступні критерії:

- узгодженість інвестиційної стратегії фірми з загальною стратегією їі економічного розвитку; тегії; 


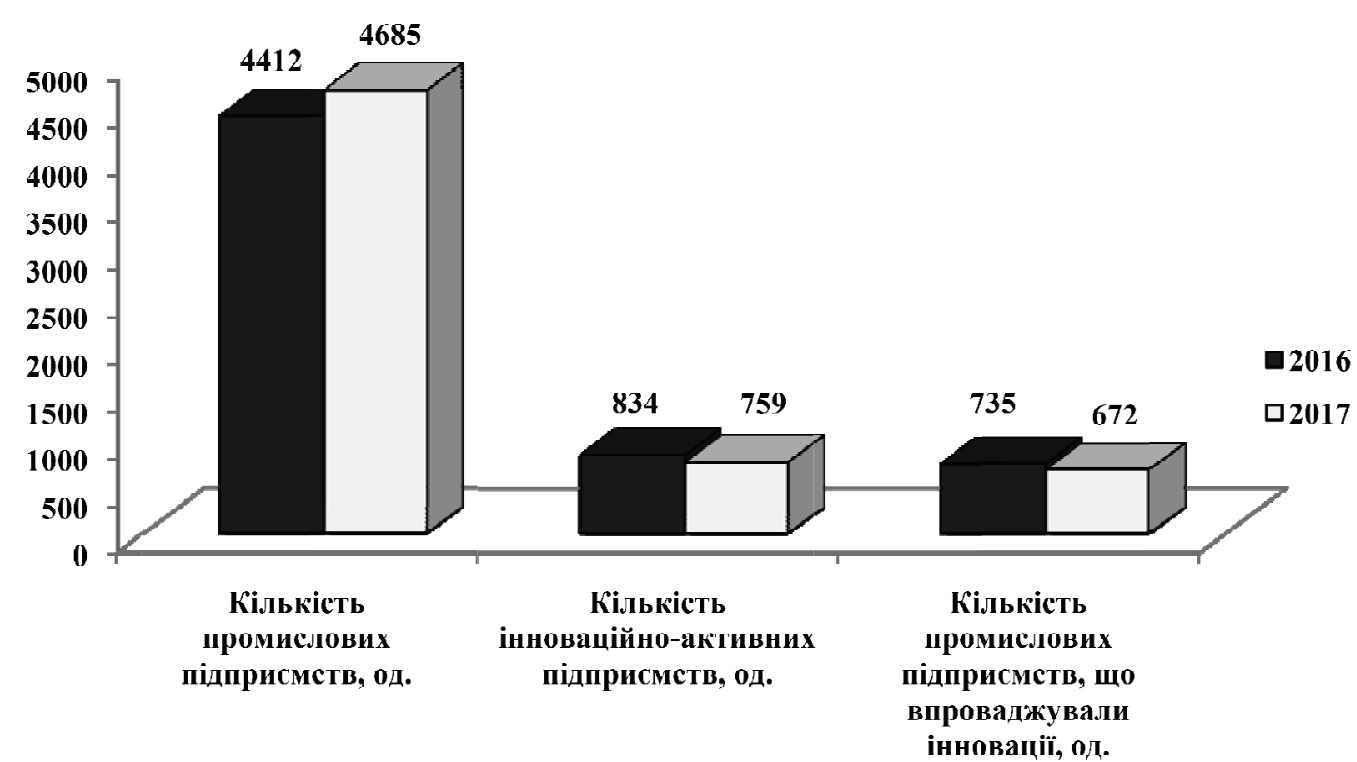

Рис. 3. Динаміка основних показників інноваційної діяльності промислових підприємств у період $2016-2017$ рр.

- узгодженість інвестиційної стратегії з зовнішнім середовищем;

- можливість реалізації інвестиційної стратегії 3 урахуванням існуючого ресурсного потенціалу;

- рівень ризику, пов'язаного 3 реалізацією інвестиційної стратегії;

- результативність інвестиційної стратегії, яка базується на визначенні економічної ефективності їі реалізації.

Таким чином, розробка інвестиційної стратегії дозволяє приймати ефективні управлінські рішення, пов'язані з розвитком підприємства в нестабільних економічних умовах [9].

Сталий розвиток $є$ найважливішою характеристикою промислових підприємств, що функціонують в умовах нестабільного зовнішнього середовища. Якщо промислове підприємство стійко розвивається, то воно має ряд переваг перед іншими суб'єктами господарювання в залученні інвестицій, кредитів, впровадження результатів НТП, виборі контрагентів, підборі кваліфікованих кадрів. Водночас промислове підприємство не вступає в конфлікт з державою, суспільством і екосистемою, оскільки сплачує своєчасно і в повному обсязі податки, платежі, збори, виплачує гідну заробітну плату, диві- денди, здійснює природоохоронну і ресурсозберігаючу діяльність.

Чим вище рівень стійкості промислового підприємства, тим воно більш незалежно від несподіваної зміни зовнішньої кон'юнктури і, отже, менше ризик банкрутства і повного припинення функціонування.

Визначальним у забезпеченні сталого розвитку $є$ його інноваційне спрямування, що грунтується на активному використанні знань і наукових досягнень, стимулюванні інноваційної діяльності, створенні сприятливого інвестиційного клімату, оновленні виробничих засобів, формуванні високотехнологічних видів діяльності та галузей економіки, підвищенні енергоефективності виробництва, стимулюванні збалансованого економічного зростання.

Так, у 2017 році відбулося скорочення кількості інноваційно-активних промислових підприємств порівняно з 2016 р. до 16,2 \% проти 18,9 \% загальної кількості промислових підприємств. У порівнянні з 2016 р. кількість промислових підприємств, що впроваджували інновації у 2017 р. зменшилась до 14,3 \% проти $16.6 \%$ загальної кількості промислових підприємств, кількість упроваджених інноваційних товарів та послуг зменшилась на 57,7 \%, що відбулося внаслідок значного скоро-

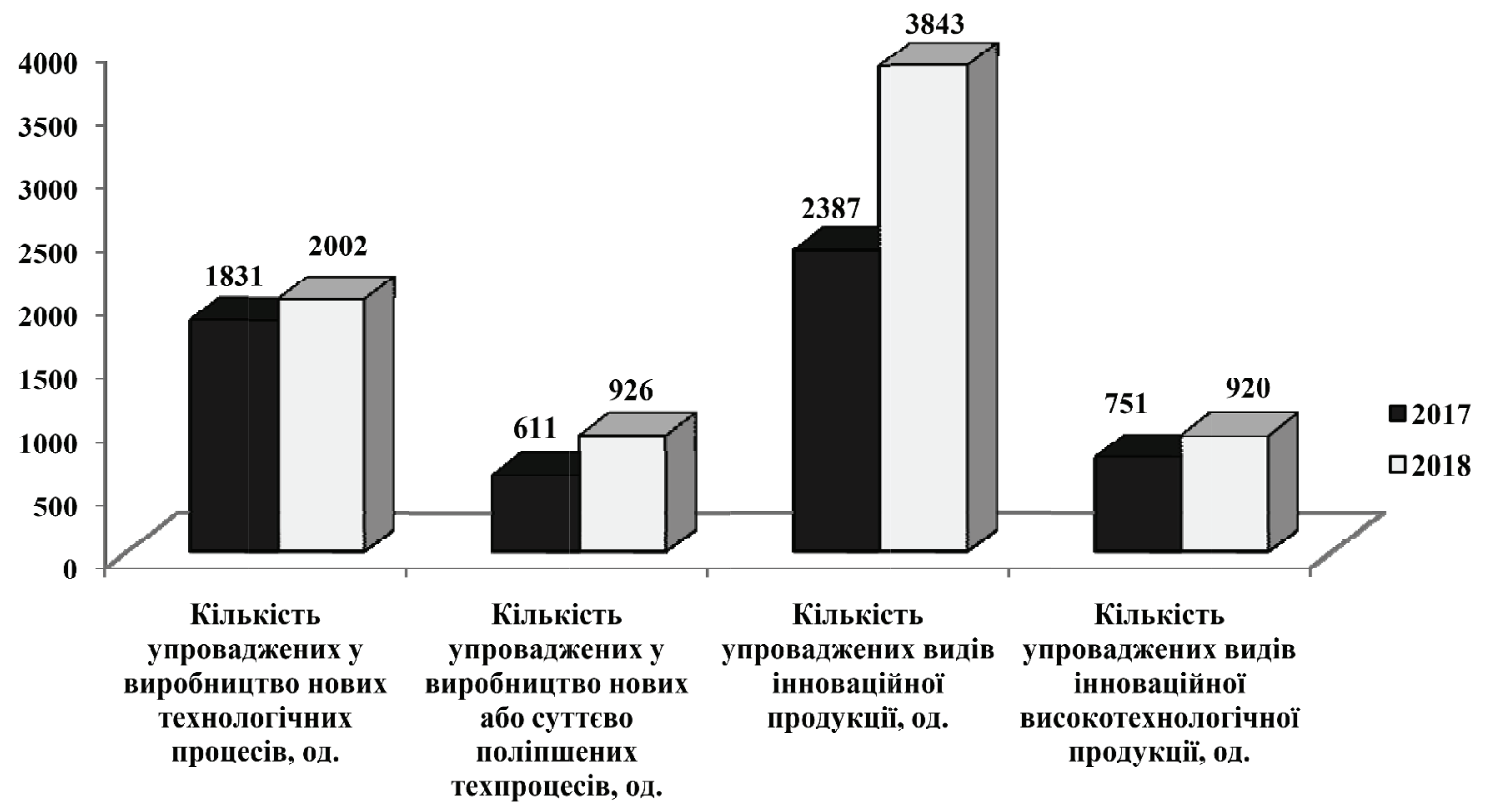

Рис. 4. Інноваційна активність промислових підприємств у період 2017-2018 рр. 
Таблиця 1. Проблеми та рішення стратегічних цілей

\begin{tabular}{|c|c|c|}
\hline Проблеми & Рішення & Стратегічні цілі \\
\hline $\begin{array}{l}\text { - Незахищені права приватної } \\
\text { власності. } \\
\text { - Нестабільна та недосконала } \\
\text { нормативна база }\end{array}$ & $\begin{array}{l}\text { Оптимізація } \\
\text { нормативно-правової } \\
\text { бази }\end{array}$ & \multirow{2}{*}{$\begin{array}{l}\text { Ціль } 1 . \\
\text { Ділове середовище в Україні } \\
\text { сприятливе для } \\
\text { налагодження, } \\
\text { функціонування та розвитку } \\
\text { підприємництва }\end{array}$} \\
\hline $\begin{array}{l}\text { - Негативне сприйняття великого } \\
\text { бізнесу в суспільстві. } \\
\text { - Брак менеджерів/професіоналів } \\
\text { здатних до творчого мислення }\end{array}$ & $\begin{array}{l}\text { Розвиток } \\
\text { підприємницької } \\
\text { культури та людських } \\
\text { ресурсів }\end{array}$ & \\
\hline $\begin{array}{l}\text { - Висока енергоємність } \\
\text { виробництва. } \\
\text { - Низька ефективність праці. } \\
\text { - Низька інноваційна активність }\end{array}$ & $\begin{array}{l}\text { Прискорення передачі } \\
\text { технологій та інновацій }\end{array}$ & \multirow{2}{*}{$\begin{array}{l}\text { Ціль } 2 . \\
\text { Середні підприємства } \\
\text { створюють базу для } \\
\text { національної економіки, } \\
\text { забезпечуючи найбільший } \\
\text { обсяг виробництва, } \\
\text { інвестицій, зайнятості та } \\
\text { доходів }\end{array}$} \\
\hline $\begin{array}{l}\text { • Значна частка збиткових } \\
\text { підприємств }\end{array}$ & $\begin{array}{l}\text { Санація та усунення } \\
\text { неплатоспроможності } \\
\text { «чесних» підприємств }\end{array}$ & \\
\hline $\begin{array}{l}\text { - Висока вартість боргу. } \\
\text { - Низька ліквідність українського } \\
\text { фондового ринку. } \\
\text { • Обмежена кількість інструментів } \\
\text { фінансування }\end{array}$ & $\begin{array}{l}\text { Збільшення доступу до } \\
\text { фінансування }\end{array}$ & \multirow[t]{2}{*}{$\begin{array}{l}\text { Ціль } 3 . \\
\text { Малі підприємства } є \\
\text { найбільш динамічними та } \\
\text { інноваційними суб'єктами } \\
\text { господарювання в економіці } \\
\text { України }\end{array}$} \\
\hline • Неефективність бізнесу & $\begin{array}{l}\text { Покращення управління } \\
\text { бізнесом }\end{array}$ & \\
\hline $\begin{array}{l}\text { - Недостатня кількість якісних } \\
\text { стартапів }\end{array}$ & $\begin{array}{l}\text { Сприяння } \\
\text { підприємництву }\end{array}$ & \multirow{3}{*}{$\begin{array}{l}\text { Ціль } 4 . \\
\text { В Україні діє ефективна } \\
\text { інфраструктура підтримки } \\
\text { бізнесу (державна та } \\
\text { приватна) }\end{array}$} \\
\hline $\begin{array}{l}\text { • Неефективний діалог з органами } \\
\text { державної влади. } \\
\text { • Обмежена співпраця між } \\
\text { різними сегментами бізнесу }\end{array}$ & $\begin{array}{l}\text { Створення ефективних } \\
\text { підприємницьких мереж }\end{array}$ & \\
\hline $\begin{array}{l}\text { • Обмежений доступ до } \\
\text { державних закупівель }\end{array}$ & $\begin{array}{l}\text { Збільшення доступу до } \\
\text { державних закупівель }\end{array}$ & \\
\hline $\begin{array}{l}\text { • Обмежені можливості експорту. } \\
\text { - Низька участь у глобальному } \\
\text { ланцюжку вартості. } \\
\text { • Обмежене різноманіття } \\
\text { експортних товарів та послуг. } \\
\text { • Залежність від глобального } \\
\text { ринкового середовища }\end{array}$ & $\begin{array}{l}\text { Збільшення доступу до } \\
\text { торгових зон }\end{array}$ & $\begin{array}{l}\text { Ціль 5. } \\
\text { Підприємства в Україні є } \\
\text { конкурентоспроможними на } \\
\text { світовому ринку, працюють } \\
\text { ефективно та виробляють } \\
\text { товари з високою доданою } \\
\text { вартістю }\end{array}$ \\
\hline
\end{tabular}

чення упровадження високотехнологічної продукції (на 57,5\% порівняно з 2016р). Водночас обсяг виділених на інновації коштів скоротився 323229,5 млн грн до 9117,5 млн грн (рис. 3).

Проте у 2018 р. фіксується зростання інноваційної активності промислових підприємств (рис. 4), як у частині кількості впроваджених у виробництво нових технологічних процесів, видів інноваційної продукції, обсягу реалізованої інноваційної продукції,так й витрат на інновації та фінансування інноваційної діяльності.

Найбільш проблемними питаннями готовності промисловості України до сталого розвитку з точки зору інновацій також є:

- державні організації та установи, які не зацікавлені у закупівлі нової технологічної продукції або ж не мають достатнього фінансування для цього;

- частка підприємств, які готові сприймати й впроваджувати інновації у свій виробничий процес залишається незначною.

- недостатнє фінансування;

- недосконалість законодавчої бази у сфері інновацій та податкової системи;

- міграція "розуму" в інші країни тощо.

Все це обумовлює необхідність удосконалення елементів механізму управління сталим розвитком промислових підприємств.

Вагомими функціональними складовими, які визначають сталий розвиток вітчизняних промислових підприємств на макрорівні, є наступні: економічна, науково-технічна, соціальна та екологічна.

Економічна сталість характеризує забезпеченість підприємства фінансовими ресурсами. Науково-технічна сталість пов'язана з оцінкою стану та ефективності використання засобів виробництва, змістом інвестиційної діяльності та рівнем використання останніх досягнень науко-технічного прогресу. Соціальна сталість пов'язана з оцінкою сталості складу персоналу, плинності кадрів, співвідношенням середньої заробітної плати на підприємстві з середньою заробітною платою по галузі, визначення кваліфікації персоналу, рівня дисципліни, умов праці та відпочинку тощо. Екологічна сталість характеризує екологічну відповідальність підприємства та рівень екологічної безпеки виробництва.

Україна представлена у кількох міжнародних рейтингах, які оцінюють інноваційну та технологічну конкурентоспроможність, інноваційний потенціал, людський капітал, державне управління. За більшістю індикаторів Україна знаходиться на рівні світових та європейських аутсайдерів. Проведений аналіз стосовно місць, які на теперішній час займає Україна у рейтингах міжнародних організацій за основними економічними показниками, на жаль, свідчать про її низький рівень розвитку. Це є результатом того, що протягом останніх років економіка України знаходиться у стані глибокої системної кризи. У зв'язку з складною політичною та економічною ситуацією спостерігається відтік закордонних інвесторів, що негативно впливає на розвиток країни [6].

Політика стратегічного бачення. Стратегічне бачення - сприятливе середовище Аля підприємницьких структур, що створюють, розвивають та досягають довгострокового успіху незалежно від їх розміру, галузевої спеціалізації та географічних характеристик розташування в створених в Україні.

Стратегічні цілі:

1. Бізнес середовище в Україні сприятливе для створення, функціонування та розвитку підприємництва. 
2. Середні підприємства створюють базу для національної економіки шляхом забезпечення найбільшого обсягу виробництва, інвестицій, зайнятості та доходів.

3. Малі підприємства є найбільш динамічні та інноваційні суб'єкти господарювання в українській економіці.

4. Ефективна бізнес підтримка інфраструктури (державна та приватна).

5. Підприємства України є конкурентоспроможними на світовому ринку, ефективно працюють та виробляють товари з високою доданою вартістю.

Існуючі проблеми та бар'єри для розвитку підприємництва в Україні зумовлюють необхідність зміни сучасного середовища для досягнення стратегічних цілей. Виявлені проблеми охоплюють декілька ключових сфер втручання:

- Покращення кон'юнктури ринку для налагодження та управління бізнесом шляхом усунення існуючих структурних, інституційних та фінансових бар'єрів.

- Сприяння виходу українського бізнесу на нові ринки як всередині країни, так і за її межами.

- Підтримка у проведенні освітніх та навчальних програм для новоствореного та існуючого бізнесу.

- Сприяння розвитку ділових мереж шляхом створення бізнес-асоціацій, створення та розвиток галузевих, міжгалузевих та територіальних кластерів.

- Підвищення підприємницької культури та мислення в громаді шляхом сприяння підприємництву та освіті нового покоління підприємців.

Вирішення потреб, викладених у таблиці 1, призведе до якісних змін у структурі підприємництва, динаміки розвитку нового та існуючого бізнесу, примноження інновацій, посилення конкурентного потенціалу українських компаній на світовому ринку (табл. 1) [10].

\section{ВИСНОВКИ}

Жорстка конкурентна боротьба на світових ринках потребує від України пошуку шляхів підвищення конкурентоспроможності національної економіки, формування у країні потужного інноваційного та науково-технічного потенціалу. Однак високий ступінь конкурентоспроможності промислових підприємств та країни загалом характеризується наявністю механізмів формування й забезпечення умов, засобів, які зумовлюють їх розвиток та підвищення добробуту населення.

Українським підприємцям, менеджерам слід зважати на такий фактор, як конкуренція в часі. Скорочення потреби в часі для певної діяльності передбачає підвищення продуктивності і, відповідно, зниження витрат. Опанування часу охоплює аспекти швидкості, моменту часу та величини фондів.

За постійного зростання швидкості ринкових змін уміння володіти часом $є$ особливо актуальним. Швидкість, з якою підприємства пристосовуються до змін, модифікують свою діяльність, є значущим стратегічним конкурентним фактором, завдяки якому можна досягти переваг за багатьма стратегічно важливими показниками

Підприємства можуть одночасно здійснювати не одну, а кілька стратегій. Так, багатогалузеві компанії Аля одного виду товару можуть розробити стратегію глибокого проникнення на ринок (завоювання кращих позицій на даному ринку), для іншого вибрати стратегію розвитку ринку (вихід на освоєний ринок з новим продуктом) і т.д. Завдання керівництва полягає в тому, щоб при виборі стратегії всебічно врахувати конкретні умови і цілі бізнесу.

$\Lambda$ ітература:

1. Гудзь О.І. Стратегія розвитку підприємства: сутність та класифікація//Економіка і суспільство. - 2018. № $8 .-$ C. $346-352$.
2. Головчук Ю.О., Пчелянська Г.О. Особливості формування стратегії підвищення конкурентоспроможності підприємства на основі парадигми інноваційного розвитку //Економіка та держава. - 2020. - № 3. C. $66-70$.

3. Епіфанова І. Ю. Азюбко М. Ю. Формування стратегії розвитку підприємства в сучасних умовах // Вісник ОНУ ім. Т.Г. Шевченка. - 2017. - Вип. 2 (55). С. $99-$ 102.

4. Конащук В.А., Ковальова В.Ю. Формування інвестиційної стратегії промислового підприємства [Електронний ресурс]. - Режим доступу:http://www.zgia.zp.ua/gazeta/ evzdia 3_075.pdf

5. Череп А.В., Сучков А.В. Стратегічне планування i управління: навчальний посібник. К.: "Кондор", 2011. $334 \mathrm{c.}$

6. Плахотнік О.О., Чернявська I.М. Механізм забезпечення сталого розвитку промисловості україни в умовах нестабільної геополітичної ситуації// Ефективна економіка [Електронний ресурс]. - Режим доступу: http://www.economy.nayka.com.ua/pdf/3_2020/5.pdf

7. Горєлов А.О., Большенко С.Ф. Стратегія підприємства. Харків: Вид-во ХНААУ, 2010.133 с.

8. Мазаракі, А., Мельник Т. Інновації як джерело стратегічних конкурентних переваг // Вісник Київського національного торговельно-економічного університету. 2010. Вип 2. С. 5-17.

9. Чорна М. В. Проектний аналіз. Харків: Консум, 2003. 228 c.

10. Entrepreneurship development strategy: expert vision [Електронний ресурс]. - Режим доступу: https:// ukrajina.fnst.org/sites/default/files/uploads/2016/12/14/ infografikaengweb.pdf

\section{References:}

1. Hudz', O. I. (2018), "Enterprise development strategy: essence and classification", Ekonomika i suspil'stvo, vol. 8 , pp. $346-352$.

2. Holovchuk, Yu. O. and Pchelians'ka, H. O. (2020), "Features of formation of strategy of increase of competitiveness of the enterprise on the basis of paradigm of innovative development", Ekonomika ta derzhava, vol. 3, pp. $66-70$.

3. Yepifanova, I. Yu. and Dziubko, M. Yu. (2017), "Formation of enterprise development strategy in modern conditions", Visnyk ONU im.. T.H.Shevchenka, vol. 2, no. 55, pp. 99-102.

4. Konaschuk, V.L. and Koval'ova, V.Yu. (2012), "Formation of investment strategy of industrial enterprise", available at: www.zgia.zp.ua/gazeta/evzdia_3_075.pdf (Accessed 17 Apr 2020).

5. Cherep, A.V. and Suchkov, A.V. (2011), Stratehichne planuvannia i upravlinnia. [Strategic planning and management], Kondor, Kyiv, Ukraine.

6. Plakhotnik, O.O. and Cherniavs'ka, I.M. (2020) "Mechanism for ensuring the sustainable development of the Ukrainian industry in an unstable geopolitical situation", Efektyvna ekonomika, [Online], vol. 2, available at: http:// www.economy.nayka.com.ua/pdf/3_2020/5.pdf (Accessed 17 Apr 2020).

7. Horielov, D. O. and Bol'shenko, S. F. (2010), Stratehiia pidpryiemstva, [Enterprise strategy], Vyd-vo KhNADU, Kharkiv, Ukraine

8. Mazaraki, A.A. and Mel'nyk, T. (2010) "Innovation as a source of strategic competitive advantage", Visnyk Kyivs'koho natsional'noho torhovel'no-ekonomichnoho universytetu, vol. 2 pp. 5-17.

9. Chorna, M. V. (2003), Proektnyj analiz [Project analysis], Konsum, Kharkiv, Ukraine.

10. Entrepreneurship development strategy: expert vision (2016), "Ukrajina.fnst", available at: https:// ukrajina.fnst.org/sites/default/files/uploads/2016/12/14/ infografikaengweb.pdf (Accessed 15 Apr 2020).

Стаття надійшла до редакиіï 17.04.2020 p. 